\title{
ANALISIS IN VITRO AKTIVITAS ANTIBAKTERI DAUN SISIK NAGA (Drymoglossum pilosellaoides) TERHADAP BAKTERI Vibrio harveyi DAN Vibrio parahaemolyticus
}

\section{In Vitro Analysis of Dragon Scale Leaves (Drymoglossum pilosellaoides) Antibacterial Activity Against Vibrio harveyi and Vibrio parahaemolyticus Bacteria}

\author{
Azis $^{1 *}$ \\ ${ }^{1}$ Program Studi Akuakultur, Fakultas Perikanan dan Ilmu Kelautan, Universitas Borneo Tarakan, Tarakan \\ *azis.borneo@gmail.com
}

Abstrak

Penelitian ini menganalisis bioaktifitas ekstrak daun sisik naga (Drymoglossum pilosellaoides) terhadap pertumbuhan bakteri Vibrio harveyi dan Vibrio parahaemolyticus. Penelitian ini bertujuan untuk mengetahui bioaktifitas dan efektifitas antibakteri ekstrak daun sisik naga terhadap pertumbuhan bakteri $V$. harveyi dan $V$. parahaemolyticus. Pengujian daya hambat dilakukan dengan metode difusi agar menggunakan 5 variasi konsentrasi $100 \%, 50 \%, 25 \%, 12,5 \%$ dan $6,25 \%$ b/v pada media TSA (Tryptone Soya Agar) dan TCBS (Thiosulfate Citrate Bile Salts Sucrose) yang diinkubasi selama 2x24 jam. Digunakan pula antibiotik berupa chloramphenicol $10^{-1}(=30 \mu \mathrm{g})$ sebagai kontrol positif, dan sebagai kontrol negatif digunakan akuades. Ekstrak daun sisik naga. mengandung flavonoid, saponin dan tanin yang bersifat antibakteri dan memiliki kemampuan mematikan bakteri uji, dengan efektifitas diameter hambatan $V$. harveyi $14,8 \mathrm{~mm}$ pada konsentrasi $100 \% \mathrm{~b} / \mathrm{v}$, sedangkan bakteri $V$. parahaemolyticus $11,8 \mathrm{~mm}$ pada konsentrasi $50 \% \mathrm{~b} / \mathrm{v}$. Efektifitas daya hambat tertinggi pada konsentrasi $50 \%$ terhadap bakteri $V$. parahaemolitycus yaitu sebesar $45,5 \%$, Sedangkan pada konsentrasi $100 \%$ memiliki efektifitas daya hambat sebesar $56,3 \%$ terhadap bakteri $V$. harveyi.

Kata kunci: Bioaktifitas, Ekstrak daun sisik naga, Zona hambat, Vibrio harveyi, Vibrio parahaemolyticus

Abstract

The research focuses on the Antibacterial activity of dragon scale leaves (Drymoglossum pilosellaoides) towards the growth of Vibrio harveyi and Vibrio parahaemolyticus bacteria. This study aimed to determine the bioactivity and antibacterial properties of Drymoglossum pilosellaoides extract on the growth of Vibrio harveyi and Vibrio parahaemolyticus. Tests conducted by the inhibition of agar diffusion method using 5 various concentration $100 \%, 50 \%, 25 \%, 12,5 \%$ and $6,25 \%$ w/v on TSA (Tryptone Soya Agar) and TCBS (Thiosulfate Citrate Bile Salts Sucrose) incubated for 2x24 hours. Antibiotics are also used in the form of Chloramphenicol $3 \mu$ as positive control and aquades as a negative control. The Drymoglossum pilosellaoides extract contains flavonoids, saponins and tannins which are antibacterial and the ability to kill bacteria test, the effectiveness of barriers $V$. harveyi diameter $14.8 \mathrm{~mm}$ at a concentration of $100 \% \mathrm{~b} / \mathrm{v}$, while the bacterium $V$. parahaemolyticus $11.8 \mathrm{~mm}$ at a concentration of $50 \% \mathrm{~b} / \mathrm{v}$. The effectiveness of the highest inhibition at a concentration of $50 \%$ against bacteria $V$. parahaemolitycus that is equal to $45.5 \%$, whereas at a concentration of $100 \%$ has the effectiveness of inhibition of $56.3 \%$ against bacteria $V$. harveyi.

Keywords : Bioactivity, Dragon scales leaf extract, Barriers zone, Vibrio harveyi, Vibrio parahaemolyticus

\section{PENDAHULUAN}

Bakteri merupakan organisme prokariot hidup terdapat hampir di seluruh ekosistem dengan berbagai bentuk kehidupan, yaitu bebas, parasit dan patogen. Sifat patogen tersebut menimbulkan kerugian, sebab bakteri dapat menyebabkan infeksi dan akhirnya dapat menimbulkan penyakit pada organisme lain termasuk ikan dan udang. Penyakit pada udang dapat disebabkan oleh bakteri, jamur, virus dan parasit yang terdapat di perairan. Penyakit yang disebabkan oleh bakteri, selain dapat menyebabkan kematian massal juga mengganggu kualitas udang dengan menurunkan mutu daging udang yang terinfeksi sehingga tidak disukai oleh konsumen.

Salah satu penyakit bakteri pada udang disebabkan oleh bakteri Vibrio harveyi dan Vibrio parahaemolyticus. Serangan dari kedua bakteri ini dapat menim- 
bulkan kerugian cukup besar bagi pembudidaya udang di Indonesia.

Penanggulangan penyakit pada udang biasanya menggunakan zat kimia atau antibiotik. Penggunaan antibiotik dapat menimbulkan resistensi terhadap bakteri, jamur, virus, dan parasit. Selain itu juga membutuhkan biaya yang cukup besar serta dapat mencemari lingkungan.

Evolusi strain bakteri yang berperan sebagai agen penyebar penyakit dan resistensi antibiotik, menjadi perhatian besar bagi kesehatan masyarakat secara global (Jawetz, 2007). Resistensi terhadap antibiotik mempengaruhi aktivitas dan perkembangan bakteri, sehingga jumlahnya dapat meningkat di perairan. Penanggulangan secara alami dengan memanfaatkan ekstrak tanaman merupakan salah satu alternatif.

Beberapa tanaman mengandung senyawa yang bersifat antimikroba yang dapat dimanfaatkan untuk menghambat pertumbuhan dan membunuh agen penyebab penyakit, salah satunya adalah daun sisik naga (Drymoglossum pilosellaoides). Dibandingkan dengan antibiotik sintesis, senyawa bioaktif yang diturunkan dari tanaman bersifat alami, tidak beracun, bebas residu dan ideal sebagai bahan pakan tambahan.

Daun sisik naga banyak dimanfaatkan terutama sebagai antibakteri dan antijamur (Somchit, 2011). Ekstrak daun sisik naga dapat menghambat pertumbuhan bakteri Propionibacterium acne dan bakteri Shigella dysentriae Febriani (2015). Kandungan yang terdapat di dalam daun sisik naga sebagai antibakteri adalah flavonoid, saponin dan tanin (Somchit, 2011).

Hal tersebut dapat diketahui dari adanya zona hambatan yang terbentuk (Tjokronegoro dan Utama, 2002). Atas dasar tersebut, maka perlu dilakukan penelitian untuk mengetahui potensi ekstrak daun sisik naga $D$. pilosellaoides sebagai antibakteri terhadap $V$. harveyi dan $V$. parahaemolyticus penyebab penyakit pada udang.
Tujuan penelitian ini untuk mengetahui daya antimikroba dan efektifitas daya hambat ekstrak daun sisik naga $D$. pilosellaoides terhadap bakteri $V$. harveyi dan $V$. parahaemolyticus secara in vitro.

\section{METODOLOGI}

\section{Waktu dan Tempat}

Penelitian ini dilakukan pada bulan Juli - September 2018 di Laboratorium Nutrisi FPIK UBT.

\section{Materi Penelitian}

Alat yang digunakan dalam preparasi sampel antara lain blender, nampan, timbangan analitik dan spatula. Ekstraksi: erlenmeyer, gelas ukur, beaker glass, hot plate with stirrer dan evaporator. Kultur bakteri: jarum ose, cawan petri, bunsen, inkubator dan laminair flow. Uji aktivitas antibakteri: mikropipet, pippet tip, kertas cakram, pinset, bunsen dan jarum ose. Pengamatan zona hambat pertumbuhan bakteri: jangka sorong. Bahan yang digunakan dalam penelitian ini yaitu daun sisik naga yang telah dihaluskan dan etanol 70\%, alkohol, akuades steril, media agar miring TSA (Tryptone Soya Agar) TCBS (Thiosulfate Citrate Bile Salts Sucrose), chloramphenicol $250 \mathrm{~g}$, etanol 96\%, isolat bakteri $V$. harveyi dan $V$. parahaemolyticus diperoleh dari Balai Besar Perikanan Budidaya Air Payau (BBPBAP) Jepara dan Stasiun Karantina Ikan Tarakan.

\section{Rancangan Penelitian}

Sebelum uji aktivitas antibakteri, terlebih dahulu dilakukan perhitungan total bakteri melalui total plate count method terhadap mikroba yang akan digunakan. Selanjutnya, uji aktivitas antibakteri tepung daun sisik naga terhadap bakteri pathogen $V$. harveyi dan $V$. parahaemolyticus dengan menggunakan metode difusi agar sumuran (well diffusion agar). Larutan tepung daun sisik naga yang diujicobakan terdiri dari 5 konsentrasi larutan, 2 kontrol (positif dan negative) : $100 \%, 50 \%, 25 \%, 12,5 \%$ dan $6,25 \%$. Sebagai kontrol positif digunakan antibiotik chloramphenicol $10^{-1}(=30 \mu \mathrm{g})$, 
dan sebagai kontrol negatif digunakan akuades.

Pengamatan dilakukan dengan mengukur diameter zona bening di sekitar sumuran pada masing-masing variasi konsentrasi ekstrak daun sisik naga, kontrol positif dan kontrol negatif dengan menggunakan jangka sorong terhadap pertumbuhan bakteri $V$. harveyi dan $V$. parahaemolyticus, zona hambat yang terbentuk sebagai parameter utama diukur dari zona hambat vertikal dan horizontal kemudian dirata-ratakan (Paliling et al., 2016).

Parameter penunjang untuk efektivitas daya hambat berbagai ekstrak bahan tumbuhan dari antibiotik dihitung berdasarkan persamaan (Arora dan Bhardwaj, 1997). Uji aktivitas antibakteri secara in vitro dianalisis secara deskriptif. Pengukuran dilakukan pada masa inkubasi selama 24 jam dan dilanjutkan hingga 48 jam. Data yang diperoleh dari hasil pengukuran ditabulasi dan dianalisis dengan cara membandingkan diameter zona hambatan untuk semua konsentrasi.

\section{Analisis Data}

Parameter penunjang untuk efektivitas daya hambat ekstrak daun sisik naga dari antibiotik dihitung berdasarkan persamaan (Arora dan Bhardwaj, 1997), yaitu:

$\mathrm{E}=\left(\frac{\mathrm{D}}{\mathrm{Da}}\right) \times 100 \%$

Keterangan:

E : Efektivitas daya hambat (\%)

D : Diameter zona hambat ekstrak bahan tumbuhan $(\mathrm{mm})$

Da : Diameter zona hambat antibiotik (mm)

\section{HASIL DAN PEMBAHASAN}

Penelitian meliputi penghitungan jumlah mikroba yang digunakan melalui metode hitungan cawan (total plate count) dan uji aktivitas antibakteri yang dilakukan dengan metode difusi agar sumuran. Uji tersebut dilakukan untuk mengukur diameter zona bening yang merupakan petunjuk adanya penghambatan partumbuhan bakteri oleh suatu senyawa antibakteri.

Total koloni 2 jenis bakteri yang digunakan dalam penelitian ini dapat dilihat pada Tabel 1. Dari hasil TPC maka jumlah bakteri yang dapat digunakan dalam uji aktivitas antibakteri adalah $10^{6} \mathrm{CFU} / \mathrm{ml}$. Syarat jumlah bakteri untuk uji kepekaan sensivisitas yakni $10^{5}-10^{8} \mathrm{CFU} / \mathrm{ml}$ (Lavilla et al., 1990).

Tabel 1. Hasil perhitungan total koloni bakteri.

\begin{tabular}{llllr}
\hline \multicolumn{1}{c}{ Isolat } & \multicolumn{3}{c}{ Pengenceran } & Total \\
& $10^{2}$ & $10^{3}$ & $10^{4}$ & $(\mathrm{CFU} / \mathrm{ml})$ \\
\hline V. harveyi & TBUD & Spread & 157 & $1,57 \times 10^{6}$ \\
V. parahaemolyticus & TBUD & TBUD & 203 & $2,03 \times 10^{6}$ \\
\hline
\end{tabular}

Keterangan: $\mathrm{TBUD}=$ terlalu banyak untuk dihitung; spread = menyebar

\section{Uji Aktivitas Antibakteri}

Hasil uji difusi agar sumuran (Tabel 2) menunjukkan bahwa ekstrak daun sisik naga dengan konsentrasi $100 \%$ sampai $6,25 \%(\mathrm{~b} / \mathrm{v})$ dapat menghambat bakteri $V$. harveyi pada zona hambat 19,37 - 20,64 $\mathrm{mm}$ dan $V$. parahaemolyticus pada zona hambat 18,59 - 19,97 mm pada 24 jam inkubasi. Sedangkan pada inkubasi 48 jam $V$. harveyi pada zona hambat $21,32-24,64$ $\mathrm{mm}$ dan $V$. parahaemolyticus pada zona hambat $18,94-22,93 \mathrm{~mm}$. Sementara itu
Amoxicillin dapat menghambat bakteri pada zona hambat $25,09 \mathrm{~mm}$.

Hasil uji daya hambat kelima konsentrasi ekstrak daun sisik naga memperlihatkan bahwa semakin tinggi konsentrasinya maka semakin besar pula zona bening yang terbentuk di sekitar sumuran. Selain itu, kontrol (+) juga mampu menghambat pertumbahan bakteri dengan adanya zona hambat yang terbentuk di sekitar media, sedangkan untuk kontrol (-) tidak membentuk zona hambat pada media. 
Adapun hasil pengukuran zona hambat pada masa inkubasi 24 jam hingga 48 jam dapat dilihat pada Tabel 2.

Tabel 2. Hasil pengukuran diameter zona hambat terhadap bakteri $V$. harveyi dan $V$. parahaemolyticus dengan masa inkubasi 24 jam dan 48 jam.

\begin{tabular}{clccccccc}
\hline \multirow{2}{*}{$\begin{array}{c}\text { Waktu } \\
\text { (jam) }\end{array}$} & \multirow{2}{*}{ Isolat bakteri } & \multicolumn{7}{c}{ Rata-rata diameter zona hambat $(\mathrm{mm})$} \\
\multirow{2}{*}{24} & V. harveyi & $4,25 \%$ & $12,5 \%$ & $25 \%$ & $50 \%$ & $100 \%$ & $\mathrm{~K}^{+}$ & $\mathrm{K}^{-}$ \\
48 & $V$. parahaemolyticus & 5,2 & 6,1 & 10,3 & 12,6 & 12,6 & 25,1 & 0 \\
& $V$. harveyi & 4,9 & 7,2 & 10,3 & 10,6 & 10,5 & 25,4 & 0 \\
& $V$. parahaemolyticus & 5,3 & 8,2 & 10,1 & 11,8 & 11,1 & 25,9 & 0 \\
\hline
\end{tabular}

Umumnya, diameter zona hambat cenderung meningkat sebanding dengan meningkatnya konsentrasi ekstrak. Akan tetapi, dalam uji ini terjadi tidak seperti pada umumnya serta zona hambat yang dihasilkan tidak stabil pada beberapa konsentrasi. Konsentrasi ekstrak daun sisik naga pada konsentrasi $50 \%$ dan $100 \%$ memberikan respon rata-rata zona hambat terhadap bakteri $V$. harveyi sebesar 12,6 $\mathrm{mm}$ pada pengamatan 24 jam dan mengalami peningkatan zona hambat sebesar $2,3 \mathrm{~mm}$ dan $2,4 \mathrm{~mm}$ pada pengamatan 48 jam.

Zona hambat terhadap bakteri $V$. parahaemolitycus pada konsentrasi 50\% dan $100 \%$ memberikan respon zona hambat sebesar 10,6 dan 10,5 atau mengalami penurunan nilai zona hambat rata-rata sebesar $0,1 \mathrm{~mm}$ pada pengamatan 24 jam. Sedangkan pada pengamatan 48 jam memiliki nilai rata-rata zona hambat sebesar $11,8 \mathrm{~mm}$ dan $11,1 \mathrm{~mm}$ atau mengalami penurunan nilai zona hambat sebesar $0,7 \mathrm{~mm}$ dari konsentrasi $50 \% \mathrm{ke}$ konsentrasi $100 \%$.

Hasil tersebut menunjukkan bahwa peningkatan konsentrasi ekstrak daun sisik naga tidak berbanding lurus dengan peningkatan zona hambat terhadap perkembangan bakteri $V$. harveyi dan $V$. parahaemolitycus. Menurut Stout dan Davis (1971), diameter zona hambat yang dibentuk tidak selalu naik sebanding dengan naiknya konsentrasi ekstrak, hal ini disebabkan karena adanya perbedaan kecepatan difusi senyawa antibakteri pada media agar serta jenis dan konsentrasi senyawa antibakteri yang berbeda juga memberikan diameter zona hambat yang berbeda pada waktu tertentu.

Selain itu, perbedaan diameter zona hambat pada masing-masing perlakuan dipengaruhi oleh beberapa faktor. Faktor faktor tersebut antara lain adalah konsentrasi senyawa antibakteri, jumlah bakteri, jenis bakteri, dan suhu (Pelczar dan Chan, 1986).

Hasil pengamatan zona hambat yang dihasilkan dari masing-masing perlakuan memiliki diameter yang berbeda serta bentuk yang tidak beraturan. Oleh karena itu, pengamatan dilakukan dengan cara mengukur diameter zona hambat yang terbentuk secara vertikal dan horizontal, dari zona yang terbentuk di sekitar lubang sumuran. Hasil pengujian menunjukkan bahwa kategori zona hambat yang terbentuk oleh ekstrak daun sisik naga terhadap pertumbuhan bakteri $V$. harveyi dan $V$. parahaemolitycus pada konsentrasi 50\% dan 100\% termasuk dalam kategori kuat.

Menurut Stout dan Davis (1971) diameter zona hambat yang terbentuk pada uji in vitro sebesar $10-20 \mathrm{~mm}$ termasuk dalam kategori kuat. Sedangkan hasil pengujian zona hambat pada kontrol negatif tidak menghasilkan zona hambat, dikarenakan larutan yang digunakan adalah aquades yang tidak memiliki senyawa antibakteri. Sedangkan diameter zona hambat yang dihasilkan oleh kontrol positif chloramphenicol menunjukkan perbedaan dengan nilai rata - rata $24,60 \pm 1,90 \mathrm{~mm}$, hal 
ini dikarenakan chloramphenicol merupakan bahan kimia antibiotik bakteriostatik.

Zona hambat di sekitar kertas cakram menunjukkan adanya aktivitas antibakteri. Zona hambat yang terbentuk, diduga adanya kandungan senyawa bioaktif sebagai antibakteri dari ekstrak daun sisik naga yang mampu menghambat pertumbuhan bakteri $V$. harveyi. Sejalan dengan pendapat Azis (2016) zona hambat di sekitar kertas cakram merupakan daerah difusi ekstrak yang mempengaruhi pertumbuhan bakteri.

Efektivitas daya hambat ekstrak daun sisik naga diperoleh dengan membandingkan nilai zona hambat bahan tumbuhan dengan nilai zona hambat dari kontrol positif yaitu larutan antibiotik chloramphenicol. Efektivitas daya hambat ekstrak daun sisik naga terhadap bakteri $V$. harveyi dapat dlihat pada Tabel 3.

Tabel 3. Efektivitas daya hambat ekstrak daun sisik naga selama 48 jam terhadap pertumbuhan bakteri $V$. harveyi dan $V$. parahaemolitycus.

\begin{tabular}{|c|c|c|}
\hline \multirow{2}{*}{$\begin{array}{c}\text { Perlakuan } \\
(\%)\end{array}$} & \multicolumn{2}{|c|}{ Efektivitas Ekstrak (\%) } \\
\hline & $V$. harveyi & V. parahaemolitycus \\
\hline 100 & 56,3 & 42,8 \\
\hline 50 & 54,3 & 45,5 \\
\hline 25 & 39 & 38,9 \\
\hline 12,5 & 27,3 & 31,7 \\
\hline 6,25 & 18,6 & 20,5 \\
\hline
\end{tabular}

Berdasarkan tabel 3, persentase efektivitas daya hambat ekstrak daun sisik naga menunjukkan persentase efektivitas daya hambat tertinggi terhadap pertumbuhan bakteri $V$. harveyi yaitu $56,3 \%$ pada konsentrasi $100 \%$ sedangkan pada bakteri $V$. parahaemolitycus memiliki efektifitas daya hambat terbesar pada konsentrasi 50\% sebesar $45,5 \%$.

Hal ini diduga karena adanya perbedaan senyawa antibakteri pada masingmasing ekstrak dalam menghambat pertumbuhan bakteri $V$. harveyi dan $V$. parahaemolitycus. Pada penelitian Azis (2016) mengenai efektivitas daya hambat ekstrak bawang tiwai terhadap pertumbuhan bakteri Aeromonas hydrophila, bahwa ekstrak bawang tiwai dengan konsentrasi 30\% menunjukkan efektivitas antibakteri tertinggi terhadap bakteri $A$. hydrophila sebesar $72,5 \%$, sedangkan pada konsentrasi $40 \%$ dan $50 \%$ terlihat bahwa efektivitas antibakterial dari ekstrak bawang tiwai semakin menurun yaitu masingmasing sebesar 54\% dan $47 \%$.

Efektifitas daya hambat ekstrak daun sisik naga terhadap bakteri $V$. harveyi dan $V$. parahaemolitycus disebabkan oleh kandungan senyawa bioaktif pada ekstrak daun sisik naga yang dapat merusak sistem sintesa protein, kerusakan dinding sel yang menyebabkan lisis sehingga terjadi kerusakan dinding sel yang dapat mengganggu mekanisme sintesis dinding sel bakteri.

Menurut Jawetz (2007), pertumbuhan bakteri yang terhambat atau kematian bakteri akibat adanya penghambatan terhadap sintesis protein oleh senyawa senyawa bioaktif. Ketahanan bakteri gram negatif dan gram positif terhadap senyawa antibakteri berbeda-beda. Perbedaan kepekaan bakteri gram negatif dan gram positif berkaitan dengan struktur dalam dinding sel, seperti jumlah peptidoglikan (adanya reseptor, pori-pori dan lipid), sifat ikatan silang dan aktivitas enzim autolik. Komponen tersebut merupakan faktor yang menentukan penetrasi, pengikatan dan aktivitas senyawa antimikroba.

Mekanisme penghambatan antibakteri terhadap pertumbuhan bakteri dapat berupa kerusakan dinding sel yang mengakibatkan lisis atau penghambatan sintesis dinding sel, pengubahan permeabilitas membrane sitoplasma sehingga menyebabkan keluarnya bahan makanan 
melalui dinding sel, denaturasi protein sel dan perusakan sistem metabolisme di dalam sel dengan cara penghambatan kerja enzim intraseluler (Pelczar dan Chan, 2008).

\section{KESIMPULAN DAN SARAN Kesimpulan}

Setelah dilakukan penelitian maka diperoleh beberapa kesimpulan, yaitu bioaktifitas ekstrak daun sisik naga (Drymoglossum pilosellaoides) bersifat bakteriosida yang ditunjukkan oleh peningkatan zona bening diameter zona bening setelah 24 dan 48 jam inkubasi.

Selain itu efektifitas ekstrak daun sisik naga diperoleh pada konsentrasi 50\% terhadap bakteri $V$. parahaemolitycus. Sedangkan untuk bakteri $V$. harveyi pada konsentrasi $100 \%$.

\section{Saran}

Perlu dilakukan penelitian lanjutan mengenai senyawa bioaktif yang lebih spesifik pada daun sisik naga (Drymoglossum pilosellaoides). sehingga masing-masing kandungan senyawa bioaktif dalam daun sisik naga dapat diketahui manfaatnya.

\section{DAFTAR PUSTAKA}

Arora, D.S. dan Bhardwaj, 1997. Antibacterial Activity of Some Medicinal Plants, Geo. Bios., 24, 127131.

Azis, 2016. Efektivitas Daya Hambat Ekstrak Bawang Tiwai (Eleutherine americana) Terhadap Pertumbuhan Bakteri Aeromonas hydrophila Secara In Vitro. J. Harpodon 10(3).

Febriani, W.D., 2015. Perbedaan Daya Hambat Ekstrak Daun Sisik Naga (Drymoglossum piloselloides Linn.) Terhadap Bakteri Propionibacterium acne Dengan Shigella dysentriae. Universitas Jember, Jember.

Jawetz, 2007. Mikrobiologi Kedokteran Jawetz, Melnick, \& Adelberg. Translation of Jawetz, Melnick, and Adelberg's. Medical Microbiology, 23th Ed. Alih bahasa oleh Hartanto, H., et al. Jakarta: EGC, Ed.23.

Lavilla, P., Baticados, M.C.L., Cruz, L.E.R., Pena, L.D. and Sunaz, N.A., 1990. Studies on the chemical control of luminous bacteria $V$. harveyi and $V$ splendidus isolated from diseased Penaeus monodon larvae and rearing water. Dis. Aquat. Org. 9: 133-139.

Paliling, A., Jimmy Posangi, P.S. dan Anindita, 2016. Uji Daya Hambat Ekstrak Bunga Cengkeh (Syzgyum aromaticum) Terhadap Bakteri Porphyromonas gingivalis. Jurnal $e G, 4(2): 230-233$.

Pelczar., M.J. dan Chan, E.C.S., 2008. Dasar-Dasar Mikroorganisme. Jakarta. Universitas Indonesia Press.

Pelczar, M.J. dan Chan, E.C.S., 1986. Dasar - Dasar Mikrobiologi Jilid I. Diterjemahkan oleh Ratna Siri Hadioetomo, Teja Imas, S. Sutami, Sri Lestari. Jakarta: Universitas Indonesia, $116-117$.

Somchit, N.M., 2011. In vitro antifungal and antibacterial activity of Drymoglossum piloselloides L. Presl. Against several fungi responsible for Athlete's foot and common pathogenic bacteria. African Journal of Microbiology Research Vol. 5 no 21.

Stout, R.T. dan Davis, W.W., 1971. Disc Plate Method of Microbiological Antibiotic Assay. Applied microbiology, p. 666-670 vol. 22, no. 4 The Lily Research Laboratories, Eli Lilly and Co., Indianapolis, Indiana 46206.

Tjokronegoro, A. dan Utama, A., 2002. Pengobatan Mutakhir Dermatologi pada Anak Remaja. Jakarta: FK UJ. 